\title{
Chapter 7 \\ Vegetation Restoration and Other Actions to Enhance Wildlife in European Agricultural Landscapes
}

\author{
José María Rey Benayas and James M. Bullock
}

\begin{abstract}
Intensive farming practices are a major cause of destruction and degradation of natural vegetation throughout the world. However, in some regions including Europe, semi-natural vegetation and farmland systems harbour wildlife of conservation concern and other values. We propose widespread strategic revegetation - a type of restoration related to wildlife-friendly farming or land sharing with little competition for land-by planting woodland islets and hedgerows for ecological restoration in extensive agricultural landscapes. This approach allows wildlife enhancement, provision of a range of ecosystem services, maintenance of farmland production, and conservation of values linked to cultural landscapes. In contrast, vegetation restoration by land separation, namely secondary succession following farmland abandonment and tree planting, would provide all these benefits only at the landscape or regional scales as this restoration type is at the expense of fieldlevel agricultural production. Furthermore, seed dispersal from revegetated elements favours passive restoration of nearby abandoned farmland and, consequently, rewilding. Revegetation of riparian systems and other actions that do not compete for land use such as introduction of bird perches, refuges for wildlife or creation of ponds would provide similar benefits. Revegetation of roadsides and roundabouts may support dispersal and spread of species but may function as ecological traps for wildlife. We provide a practioner's perspective related to land-sharing restoration actions in central Spain. We conclude that practical restoration projects-particularly strategic revegetation- are essential if we want to halt biodiversity loss and encourage the return of wildlife in agricultural landscapes.
\end{abstract}

Keywords Biodiversity $\cdot$ Farmland $\cdot$ Land separation $\cdot$ Land sharing $\cdot$ Seed dispersal $\cdot$ Strategic revegetation

\author{
J. M. Rey Benayas $(\bowtie)$ \\ Departamento de Ciencias de la Vida — UD Ecología, Universidad de Alcalá, 28871 Alcalá de \\ Henares, Spain \\ e-mail: josem.rey@uah.es \\ J. M. Bullock \\ Centre for Ecology and Hydrology, Maclean Building, Benson Lane, Crowmarsh Gifford \\ Wallingford, OX10 8BB Oxfordshire, UK \\ e-mail:jmbul@ceh.ac.uk
}

H. M. Pereira, L. M. Navarro (eds.), Rewilding European Landscapes, 


\subsection{Introduction}

A large part of environmental degradation is due to the expansion of the agricultural frontier in many parts of the world together with intensification of farming methods. For instance, Ellis and Ramankutty (2008) indicated that 14 of the World's 21 major biome types have agricultural use. Agricultural land covered 4.91 billion ha, ca. $38 \%$ of the terrestrial surface, in 2011 (FAOSTAT 2013), to the detriment of natural vegetation cover. However, at the global scale, the amount of agricultural land has currently reached a plateau (Rey Benayas and Bullock 2012), with a redistribution of agricultural land from temperate areas towards the tropics (Foley et al. 2011; Rey Benayas and Bullock 2012). In the European Union (EU-27) $43 \%$ of the land is under agriculture (FAOSTAT 2013), but this proportion is often nearly $100 \%$ at more local scales such as the Castillian plains of Spain.

A powerful approach to countering the negative impacts of agricultural expansion and intensification is ecological restoration. Restoration actions are increasingly being implemented in response to the global biodiversity crisis, and are supported by agreements such as the global Convention for Biological Diversity-a major target of its strategic plan for 2020 is restoring at least $15 \%$ of degraded ecosystems - and the EU Council's conclusions on biodiversity post-2010, e.g. "halting the loss of biodiversity and the degradation of ecosystem services in the EU by 2020 , and restoring them in so far as feasible". Such policy initiatives are useful, but raise questions about our ability to manage and restore ecosystems to supply multiple ecosystem services and biodiversity (Bullock et al. 2011). For instance, there is often a trade-off between agricultural production that meets societal needs for food and fiber $v s$. other services and conservation of biodiversity (Pilgrim et al. 2010).

Recent discussions about the future of farming have contrasted "land sharing"sometimes called "wildlife-friendly farming"- with "land separation". The former advocates the enhancement of the farmed environment, while the latter, also called "land sparing", advocates a separation of land designated for farming from that for conservation (Fischer et al. 2008; Phalan et al. 2011). Rey Benayas and Bullock (2012) argued that these approaches should not be seen as alternatives, but as representing the range of actions that can be best combined to enhance biodiversity and ecosystem services. Furthermore, considered broadly the land sharing/land separation approaches might be seen as a gradient rather than as a dichotomy as they represent actions at different spatial scales. However, when planning actions at specific locations, there is a true contrast between the land sharing and separation approaches (e.g. Phalan et al. 2011), as we will demonstrate. In this article we will first examine the complex role of agricultural systems in both delivering and harming wildlife (the so called "agriculture and conservation paradox", Rey Benayas et al. 2008). Then we focus on approaches to enhance wildlife - including rewilding - and associated ecosystem services in agricultural landscapes. On one hand, we will examine restoration actions that do not or hardly compete for land use to produce systems in which agricultural production is in partnership rather than in conflict with the enhancement of wildlife. Among the various restoration actions, we will pay particular attention to strategic revegetation by planting woodland islets 
and hedgerows. We will present a practitioner's perspective of implementation of such restoration actions in central Spain.

Cropland has mostly spread at the expense of forest land in Europe (Foley et al. 2005). Thus, on the other hand, we will focus on forest regrowth or passive restoration following farmland abandonment and tree plantations on cropland as examples of habitat restoration by land separation. Strategically revegetated elements and forest regrowth are linked by species dispersal processes. Thus, ecological restoration in farmland may maintain agricultural practices, promote wildlife return, and accelerate rewilding sensu Navarro and Pereira (see Chap. 1) in circumstances where the socio-ecological dynamics promote abandonment.

\subsection{The Agriculture and Conservation Paradox}

Few human activities are as paradoxical as agriculture in terms of their role for nature conservation. Agricultural activities are the major cause of negative environmental change worldwide. For instance, agriculture: is the main cause of deforestation; is the major threat to bird species; accounts for ca. $12 \%$ of total direct global anthropogenic emissions of greenhouse gasses; and strongly impacts on soil carbon and nutrients (sources of evidence in Rey Benayas and Bullock 2012). In recent history, in addition to an increase in farmed area, farming practices in many regions have become more intensive. For example, the area of cultivated land serviced by irrigation, the major form of human water consumption and a surrogate of farmland intensification, in Europe increased from $9.2 \times 10^{6}$ ha in 1961 to $17.9 \times 10^{6}$ ha in 2011 (FAOSTAT 2013). Beyond changes in species richness, agricultural intensification has been shown to reduce the functional diversity of plant and animal communities, potentially imperilling the provisioning of ecosystem services (Flynn et al. 2009). Importantly, intensification of land use has brought remnant areas of natural or semi-natural vegetation such as steep hillsides, property boundaries and track edges into mainstream agriculture (Rey Benayas et al. 2008). Thus, agricultural expansion and intensification have greatly increased our food, fiber and biofuels supplies, but have damaged wildlife and other services.

In contrast to these negative perspectives, extensive agricultural habitats are often viewed positively in terms of nature conservation due to, for example, creation of landscape mosaics and environmental heterogeneity (Oliver et al. 2010), or because they are threatened habitats that support endangered species and cultural values (Kleijn et al. 2006). In the EU-27, $31 \%$ of Natura 2000 sites, a network of protected areas, result from agricultural land management. Several taxa including species of birds, insects and plants, some of them endangered, depend on low-intensity farmland for their persistence (Kohler et al. 2008). Thus, common farmland birds in Europe show negative trends ( $-35 \%$ since 1980$)$ and these are today of conservation concern, whereas forest birds show positive trends due to abandonment of agricultural land and afforestation programs (European Bird Census Council 2010). Wildlife decline might affect agricultural production itself. For instance, insects that 

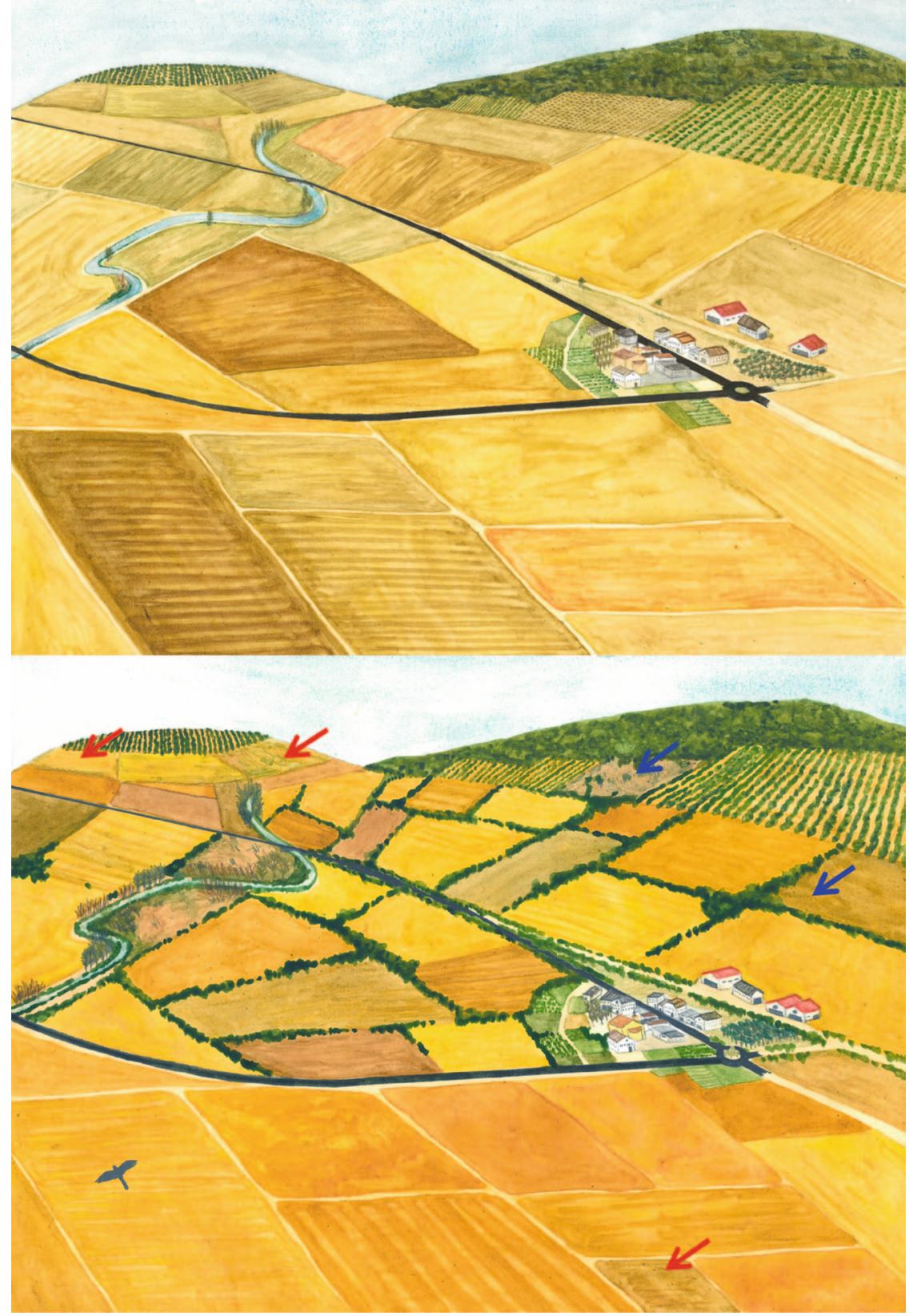

Fig. 7.1 Sketch of a hypothetical Mediterranean agricultural landscape before (top) and a few years after (bottom) implementing strategic revegetation actions. The actions illustrated are the following: (1) introduction of woodland islets and (2) hedgerows in cropfields; (3) restoration of riparian vegetation; (4) revegetation of road sides and (5) roundabouts. Additionally, there are some (6) abandoned fields, which are indicated by arrows. The lack of revegetation actions in the bottom left quarter of the landscape illustrates the inappropriateness of such revegetation due to e.g. outstanding values linked to steppe birds. Establishment and development of vegetation following cropland abandonment is different in fields close (blue arrows) or away (red arrows) from strategic revegetation actions or natural vegetation 
provide pollination and pest control services in cropland tend to be less common in more intensive landscapes (Tscharntke et al. 2005).

Agricultural intensification can have a negative impact on the values linked to traditional agriculture, but so can agricultural abandonment and, particularly, when afforestation occurs on former cropland (Rey Benayas et al. 2007). Abandonment of agricultural land has mostly occurred in developed countries in the last few decades (Rey Benayas and Bullock 2012). The European Agrarian Policy has aided afforestation in agricultural land that has resulted in the convesion of $>10^{6}$ ha of former cropland into tree plantations (Directorate-General for Agriculture and Rural Development 2012). Currently, it is providing subsidies to afforest land after vineyard extirpation in Spain, for instance, an action that is being criticized by conservationists due to negative impacts on wildlife and other values (Rey Benayas and Bullock 2012). It seems that agriculture, woodland, and biological conservation are in a permanent and irreconcilable conflict, the agriculture and conservation paradox (Rey Benayas et al. 2008).

\subsection{Designing Restoration on Agricultural Land by Strategic Revegetation}

The agriculture and conservation paradox creates a dilemma in projects that involve restoring non-agricultural habitats such as woodland on agricultural land, which can only be resolved by considering the relative values of biodiversity and ecosystem services associated with woodland vs. agricultural ecosystems (Rey Benayas et al. 2008). The reconstruction of vegetation in a landscape ("where and when to revegetate?") is an issue that has become a research priority (Thompson et al. 2009). In the context of this article, we consider as strategic revegetation, highly specific planting (and sometimes seeding) actions that are characterized as occupying a tiny fraction of the agricultural landscape (Fig. 7.1). They are intended to enhance wildlife and particular services such as habitat provision and seed dispersal. The effects on wildlife and ecosystem services will usually depend on how much land is affected by these actions.

\section{Strategic Revegetation in Farmed Fields}

In actively farmed fields, these actions can include planting woodland islets, hedgerows and isolated trees (Fig. 7.1). They have the potential to enhance wildlife, agricultural production, and other services at the field and landscape scales since they hardly compete for farmland use (Rey Benayas and Bullock 2012), and can be considered a form of rewilding per se. Rey Benayas et al. (2008) suggested a new 


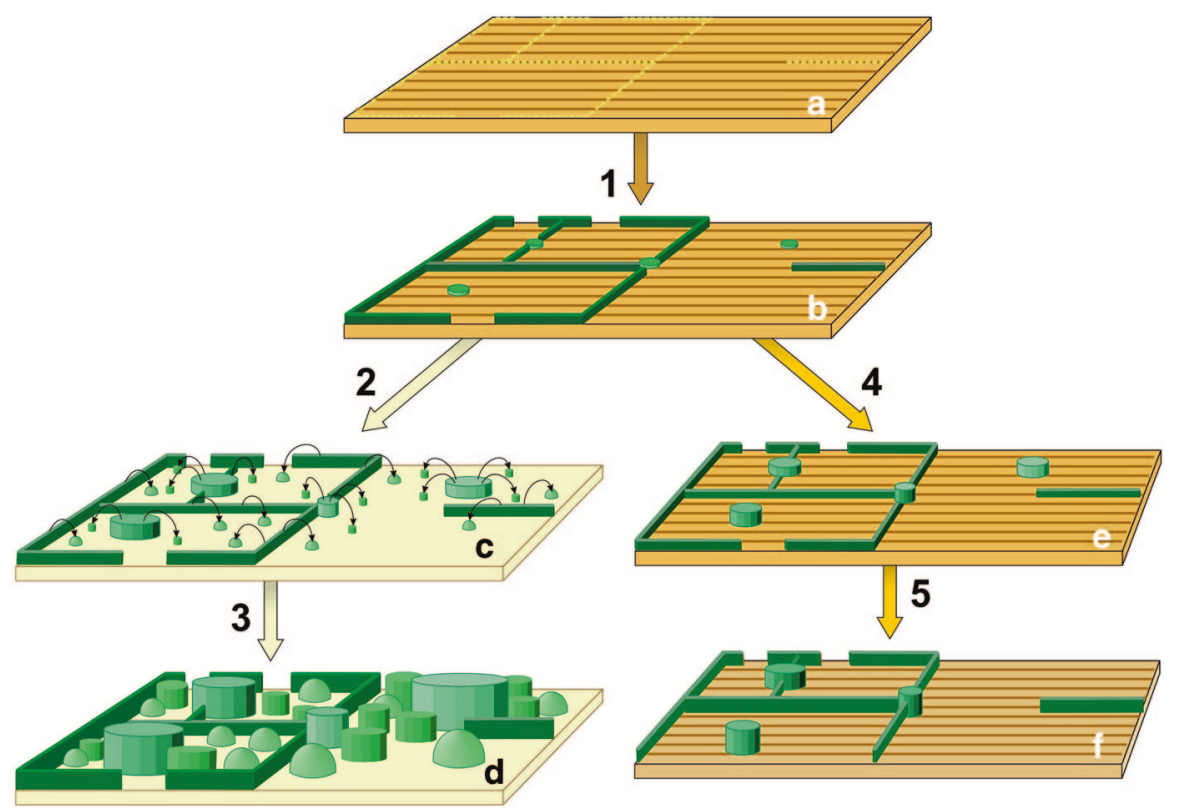

Fig. 7.2 A schematic diagram of the "woodland islet and hedgerow" model proposed in this article, based on the "woodland islets" model developed by Rey Benayas et al. (2008). A denuded agricultural landscape (a) is planted with a few (here four) small (e.g. $100 \mathrm{~m}^{2}$ ) woodland islets and hedgerows (b) Targeted management of the islets and hedgerows allows the trees to establish, grow and reach sexual maturity rapidly. If the cropland is then abandoned the islets and hedgerows can expand and export seeds (and other organisms established in them) to the surrounding land (c) The islets and hedgerows eventually coalesce to form closed woodland (d) Alternatively the surrounding land remains in same or other uses (e) while the islets and hedgerows remain as small patches of the native woodland community as the trees grow taller. Some islets and hedgerow fragments may disappear through stochastic events (f)

concept for designing restoration of forest ecosystems on agricultural land, which uses small-scale active restoration as a driver for passive restoration over much larger areas. Establishment of "woodland islets" is an approach to designing restoration of woodlands in extensive agricultural landscapes where no remnants of native natural vegetation exist. It involves planting a number of small, densely-planted, and sparse blocks of native shrubs and trees within agricultural land that together occupy a tiny fraction of the area $(<1 \%)$ of target land to be restored (Fig. 7.2). This approach, later called "applied nucleation" by Corbin and Holl (2012), allows direction of secondary succession by establishing small colonisation foci, while using a fraction of the resources required for large-scale reforestation. Woodland patches provide sources of seed and dispersing animals that can colonize adjacent habitats. If the surrounding land is abandoned, colonists from the islets could accelerate woodland development because dispersal of many woodland organisms will 
Table 7.1 Examples of seed dispersal distances for European forest and scrub species, with information on whether dispersal is biased into open or forest habitats

\begin{tabular}{|c|c|c|c|c|}
\hline Species & $\begin{array}{l}\text { Dispersal } \\
\text { vector(s) }\end{array}$ & $\begin{array}{l}\text { Maximum } \\
\text { reported } \\
\text { dispersal } \\
\text { distance }(\mathrm{m})\end{array}$ & $\begin{array}{l}\text { Biased dispersal } \\
\text { among different } \\
\text { habitats? }\end{array}$ & Reference \\
\hline Fraxinus excelsior & Wind & 90 & None & $\begin{array}{l}\text { Stoyan and } \\
\text { Wagner (2001) }\end{array}$ \\
\hline Picea abies & Wind & 150 & None & $\begin{array}{l}\text { Dovciak et al. } \\
(2008)\end{array}$ \\
\hline $\begin{array}{l}\text { Pinus sylvestris, } \\
\text { P. nigra }\end{array}$ & Wind & 100 & None & $\begin{array}{l}\text { Debain et al. } \\
(2007)\end{array}$ \\
\hline Corylus avellana & Rodents & $>70$ & Grassland $>$ woodland & $\begin{array}{l}\text { Laborde and } \\
\text { Thompson } \\
\text { (2009) }\end{array}$ \\
\hline $\begin{array}{l}\text { Corylus avellana, } \\
\text { Quercus petraea }\end{array}$ & $\begin{array}{l}\text { Jays (Garrulus } \\
\text { glandarius), } \\
\text { mice }\end{array}$ & $>200$ & $\begin{array}{l}\text { Jays: short grass }> \\
\text { tall grass/woodland } \\
\text { Mice: grassland }> \\
\text { woodland }\end{array}$ & $\begin{array}{l}\text { Kollmann and } \\
\text { Schill (1996) }\end{array}$ \\
\hline Fagus sylvatica & Jays, rodents & 3000 & Pine forest $>$ grassland & $\begin{array}{l}\text { Kunstler et al. } \\
(2007)\end{array}$ \\
\hline Prunus mahaleb & $\begin{array}{l}\text { Birds, } \\
\text { mammals }\end{array}$ & $>1500$ & $\begin{array}{l}\text { Large birds and mam- } \\
\text { mals: open }> \\
\text { scrub } \\
\text { Small birds: scrub> } \\
\text { open }\end{array}$ & $\begin{array}{l}\text { Jordano et al. } \\
\text { (2007) }\end{array}$ \\
\hline $\begin{array}{l}\text { Quercus ilex, } Q . \\
\text { suber }\end{array}$ & Jays & 550 & $\begin{array}{l}\text { Abandoned field/for- } \\
\text { est track }>\text { managed } \\
\text { field/scrub }\end{array}$ & $\begin{array}{l}\text { Pons and Pau- } \\
\text { sas (2007) }\end{array}$ \\
\hline $\begin{array}{l}\text { Quercus robur, } Q . \\
\text { petraea }\end{array}$ & Mice, voles & $>137$ & $\begin{array}{l}\text { Heath > woodland/ } \\
\text { grassland }\end{array}$ & $\begin{array}{l}\text { Jensen and } \\
\text { Nielsen (1986) }\end{array}$ \\
\hline
\end{tabular}

continue over many years (Fig. 7.1). The landscape emphasis on a planned planting of islets maximises benefits to wildlife and the potential of allowing the islets to trigger larger-scale reforestation if the surrounding land is abandoned, which can lead to rewilding (see Chap. 1). The islets should be planted with a variety of native shrub and tree species including those identified as nurse species to take advantage of facilitation processes (Cuesta et al. 2010).

Vegetation dynamics in complex landscapes depend on interactions among environmental heterogeneity, disturbance, habitat fragmentation, and seed dispersal processes. Ozinga et al. (2009) concluded that the 'colonization deficit' of plant species due to a degraded dispersal infrastructure is as important in explaining plant diversity losses as habitat quality, and called for new measures to restore the dispersal infrastructure across entire regions. Estimates of dispersal distances for vertebratedispersed shrubs and trees (Table 7.1) suggest that the introduction of woodland islets planted about one $\mathrm{km}$ apart in a deforested agricultural landscape could allow 
colonisation over the whole landscape (Rey Benayas and Bullock 2012). Spread from these islets would be facilitated in the cases where animals disperse seeds preferentially into open habitats, whilst avoiding dense scrub or forest (Table 7.1). However, the potential for colonisation from such foci will be more limited for winddispersed trees and shrubs, which seem to disperse shorter distances, and in those cases where animals disperse seeds preferentially into wooded habitats (Table 7.1). It is possible however to direct dispersal artificially into open habitats; for example by erecting structures such as perches or hedges which attract birds and/or which act as a physical barrier to wind-dispersed seeds (Bullock and Moy 2004).

The woodland islets approach maintains flexibility of land use, which is critical in agricultural landscapes where land use is subject to a number of fluctuating social, environmental, policy and economic drivers (e.g. Romero-Calcerrada and Perry 2004; Rounsevell et al 2005). It provides a means of reconciling competition for land use among agriculture, conservation and woodland restoration at the landscape scale. This could increase the economic feasibility of large-scale restoration projects and facilitate the involvement of local human communities in the restoration process. The woodland islets idea has similarities to other approaches involving planting small areas of trees on farms, such as tree clumps, woodlots, hedges, living fences, or shelterbelts and agro-forestry systems. Particularly, the revegetation of property boundaries, field margins and track edges in farmland to create living fences (Barnes and Williamson 2006; see Chap. 6) has the same function in triggering passive revegetation as woodland islets (Forget et al. 2013); thus, the "woodland islets" concept could be expanded to the "woodland islets and hedgerows" concept (Fig. 7.2). Planting isolated trees may also provide a disproportionate positive value for wildlife and potential for seed dispersal (DeMars et al. 2010; Fischer et al. 2010).

Besides providing a dispersal infrastructure, woodland islets and hedgerows provide habitat or enhance the farmed environment for wildlife. These benefits have been well documented for plant species (e.g. Poggio et al. 2010) and small animals such as insects (e.g. Noordijk et al. 2010), but they are also critical for medium-sized and even large mammals. For instance, Pereira and Rodríguez (2010) documented the value of hedgerows and narrow strips of riparian forest for the Egyptian mongoose Herpestes ichneumon and the common genet Genetta genetta. They found that mongooses and genets strongly selected linear woody vegetation, and that open fields, dehesa and olive groves were avoided. Similarly, Blanco and Cortés (2007) demonstrated that hedgerows and small woodland patches were important for wolf Canis lupus -an iconic species for the rewilding concept- living in agricultural habitats in northern Spain.

\section{Other Options for Strategic Revegetation in Agricultural Landscapes}

While we concentrate on woodlands here, the islets approach to restoring a dispersal infrastructure could be used for other (semi-)natural habitats such as species-rich grasslands, scrub, or heathland (e.g. Hooftman and Bullock 2012). Other strategic 
revegetation actions in agricultural landscapes but unrelated to the farmed environment itself could, for example, target road verges and roundabouts, and riparian systems (Fig. 7.1). These would provide similar benefits in terms of dispersal infrastructure as those explained above for woodland islets and hedgerows. The revegetation of roadsides and roundabouts may bring additional benefits such as slope stabilization and aesthetic value. However, these revegated artificial elements may also function as "ecological traps" that put at risk the wildlife attracted by them through increasing traffic collisions (Fahrig and Rytwinski 2009). Additionally, they may also decrease visibility for drivers and be dangerous obstacles in case of crashes, so safety considerations should also be considered before revegetation is decided. Thus, they should be carefully planned and supported by the planners and contractors.

Riparian systems often support the only natural or semi-natural communities at the local level in agricultural landscapes, but frequently this vegetation has been extirpated or highly degraded, and the riverside has been ploughed. It has been shown that riparian vegetation is critical for wildlife conservation (Forget et al. 2013) and provision of ecosystem services such as water regulation and purification; thus, we suggest that strategic revegetation of creeks and rivers with native species should be considered a priority in agricultural landscapes and enforced by competent public administrations.

\subsection{Restoring or Creating Other Specific Elements to Benefit Wildlife and Particular Services}

Besides strategic revegetation, there are other actions that benefit wildlife and provide particular services in farmland, which do not or hardly compete with agricultural land use. In general, all these actions were labeled "farmed field manicure" by Rey Benayas (2012) and, again, they can be considered as a form of rewilding. These include: (1) creation of pollinator-friendly areas using plant enrichment; (2) introduction of beetle banks, stone walls, stone mounds and other strategic refuges for fauna; (3) introduction of perches and nest-boxes for birds (see example below); (4) introduction or restoration of small ponds and (5) drinking troughs; and (6) reconstruction of rural architecture aiming at restoring cultural services.

GREFA's project for enhancement of birds of prey for rodent control (http://www. grefa.org/proyectosgrefa/38-proyectos/servivios-ambientales/control-biologicodel-topillo-campesino/76-control-biologico-del-topillo-campesino) is an outstanding example of this type of wildlife-friendly farming. This project was motivated by periodic field vole Microtus arvalis outbreaks, which are often controlled using poisons that may damage wildlife and game. Common kestrel Falco tinnunculus and barn owl Tyto alba are rodent predators that have declining populations for a number of reasons, including lack of sites for nesting in open landscapes. Thus, more nesting sites should increase the populations of these two species and contribute to place their populations at the carrying capacities. To achieve this goal, three 
2000-ha agricultural landscapes in central Spain were seeded with nest boxes, 100 for common kestrel and 100 for barn owl in each landscape. For common kestrel, we calculate that rodent consumption per occupied nest box is ca. $186 \mathrm{~kg} \mathrm{year}^{-1}$. As average occupancy in the three landscapes was $27 \%$ between 2009 and 2012, total rodent consumption by this species is calculated in ca. $5 \mathrm{t} \mathrm{year}^{-1}$ per landscape for those years. Total rodent consumption could be as high as ca. $46 \mathrm{t} \mathrm{year}^{-1}$ if full nest occupancy by both species was attained, a figure that is expected to contribute to both rodent damage control and the maintenance of these birds of prey.

\subsection{A Practitioner's Perspective}

The International Foundation for Ecosystem Restoration (FIRE, www.fundacionfire.org) aims at translating academic knowledge to ecosystem restoration in the real world, an example of translational ecology. It provides leadership in implementing restoration actions in farmland habitat and farmland stewardship in Spain by means of its "Fields for Life Initiative", which targets reconciliation of agricultural production and wildlife enhancement based on sound, targeted research. Since 2008 , this initiative has revegetated $6.5 \mathrm{~km}$ of hedgerows and three woodland islets of different size with ca. 12,600 seedlings of 27 native species, introduced nine artificial ponds and several hundreds of artificial nests for insectivorous birds and 121 for birds of prey, and has completed 12 signed stewardship agreements with land owners, among other achivements, including the participation of hundreds of volunteers in such actions, mostly in central Spain. The total area involved in this project is 3358 ha so far.

During these years, we have learnt that, in the first instance, farmers are reluctant to implement the suggested revegetation projects. First, farmers do not understand or forsee the benefits for agricultural production and, simultaneously, they perceive risks for crops. For instance, they believe that a new planted hedgerow is a reservoir that will spread crop pests rather than habitat for natural enemies of such pests or pollinators. They also think that the role of hedgerows as windbrakes that reduce soil erosion and dessication and crop abrasion is irrelevant for crop production. The second major reason has to do with their aesthetic appraisal of crop fields. According to their perception, crop fields must be "clean", i.e. with nothing other than the cultivated plants, and most often farmers that have "untidy" crop fields are criticized in their local communities. And third, generally, individual farmers react to the private use-value of biodiversity and ecosystem services assigned in the marketplace and thus typically ignore the 'external' benefits of conservation that accrue to wider society (Jackson et al. 2007). To overcome this reluctance, we recommend efforts to educate and show farmers that strategic revegetation and other actions benefit wildlife and wildlife-based ecosystem services that may enhance or be neutral for crop production (see also De Snoo et al. 2013). There is a need to address the inertia in farmers' perceptions, and the EU Common Agricultural Policy should 
provide specific resources to target this social objective for agricultural landowners beyond simple financial support such as the agri-environment schemes.

In contrast to such negative perceptions, and in addition to the obvious positive opinions of naturalists and conservationists, our projects are best valued and encouraged by hunters. They understand that planting woodland islets and hedgerows, the creation of ponds and other restoration actions are very beneficial to game, including birds such as the Red-legged partridge Alectoris rufa, rabbits and hares. Enhancement of game production and its associated economical benefits for local communities is an incentive for strategic restoration of agricultural fields.

The reported reluctance of farmers may be overcome; for that, we have learnt that the form of first contact with farmers is very important. The farmers need quite a lot of time to understand the possible advantages and, in the worst case, the overall non-harmful character of restoration actions in their properties. As a stewardship agreement is voluntary, it is necessary to have a continuing but 'light touch' contact with farmers to persuade them to undertake necessary actions. Once a farmer agrees to implement restoration actions on his land, other farmers in a local community often agree too. In, unfortunately, few cases we have found landowners that are rapidly persuaded to adopt restoration actions, but that are almost never willing to pay any of the cost. Thus, FIRE seeks public and private financial support for its projects on the basis of their demonstration value. In short, key issues for large-scale ecological restoration on agricultural land are financial support and education to promote farmer and public awareness and training (Rey Benayas and Bullock 2012; De Snoo et al. 2013). Land owners must be specifically rewarded for restoration actions on their properties. To reward the total or social value, tax deductions for land owners who restore agricultural land and donations to notfor-profit organizations that run restoration projects, payment for environmental services, and direct financing measures related to restoration activities should be implemented widely.

\subsection{Forest Restoration by Land Separation}

Rewilding by setting aside farmland to restore or create non-farmed habitat rarely happens - except in the case of farmland abandonment- as farmers tend to use and expand into all available land since this is usually the most profitable choice in terms of direct use value (TEEB 2010). This approach to rewilding competes with land for agricultural production at the field scale. Nevertheless, rewilding and agricultural production can coexist at the regional scale by a combination of habitat restoration and creation and maintenance of productive land for rewilding. Thus, rewilding sensu Navarro and Pereira (Chap. 1) might be considered more as land separation at the local scale, but it could also be seen a land sharing option at larger scales. Two major contrasting approaches for large-scale woodland or forest restoration in agricultural landscapes are: (1) passive restoration through secondary succession or forest regrowth following abandonment of agricultural land, e.g. cropland 
and pastures where extensive livestock farming has been removed; and (2) active restoration through addition of desired plant species. Forest regrowth and tree plantations on cropland enhance species that are characteristic of shrubland and forest environments, but are detrimental to species that are characteristic of open farmland environments and to agricultural production (Rey Benayas and Bullock 2012).

Passive restoration is cheap (although it may include opportunity costs) and leads to a local vegetation type. It is generally fast in productive environments, but slow in low productivity environments, as woody vegetation establishment is limited (Rey Benayas et al. 2008). The restoration capacity of woody ecosystems depends on the magnitude and duration of ecosystem modification, i.e., the "agricultural legacy" (Dwyer et al. 2010). A key bottleneck that hinders revegetation in large, continuous agricultural landscapes is the lack of propagules due to absence of parent trees and shrubs (García et al. 2010), which might be overcome by strategic revegetation as explained above. Passive restoration can be seen as a rewilding process (see Chap. 1), and it is of particular importance for large carnivores and herbivores such as the Brown bear Ursus arctos and the European bison Bison bonasus. The reintroduction of these species, whose habitat is expanding due to land abandonment, is often the subject of heated debates. The International Union for Conservation of Nature (2012) has recently published a document related to reintroductions and other translocations that is much more flexible than its previous 1998 Guide for such actions.

Active forest restoration basically comprises the planting of trees and shrubs (Stanturf et al. 2014). It is needed, for example, when abandoned land suffers continuing degradation, local vegetation cover cannot be recovered and secondary succession has to be accelerated. Indeed, one criticism of the passive rewilding approach is that the establishment of forest and other natural habitats in degraded landscapes may be impossible without more active interventions (Hodder and Bullock 2010). There are differences in the wildlife and ecosystem services provided by passive $v s$. active restoration, and there is much debate about the ecological benefits of tree plantations. For instance, Bremer and Farley (2010) found that plantations are most likely to contribute to biodiversity when established on degraded lands rather than replacing natural ecosystems, and when indigenous tree species are used rather than exotic species. Similarly, a meta-analysis of faunal and floral species richness and abundance in timber plantations and pasture lands on 36 sites across the world concluded that plantations support higher species richness or abundance than pasture land only for particular taxonomic groups (i.e. herpetofauna), or specific landscape features (i.e. absence of remnant vegetation within pasture) (Felton et al. 2010). Cropland afforestations in southern Europe, which are mostly based on coniferous species, may cause severe damage to populations of open habitat species, especially birds, by replacing high quality habitat and increasing risk of predation (Reino et al. 2010). Further, these planted forests have been shown to be suitable habitat for generalist forest birds but not for specialist forest birds (Sánchez-Oliver et al. 2014), whereas secondary succession shrubland and woodland favour bird species that are of conservation concern in Europe (Rey Benayas et al. 2010). 


\subsection{Conclusions}

We conclude that, although agriculture is a major cause of environmental degradation, ecological restoration on agricultural land offers opportunities to reconcile agricultural production with enhancement of wildlife and ecosystem services other than production. Strategic revegetation by land sharing through environmentallyfriendly farming, namely planting woodland islets, hedgerows and isolated trees, has the potential to enhance agricultural production, other ecosystem services and wildlife at both the farmed field and landscape scale. Importantly, strategic revegetation has the potential to trigger larger-scale reforestation if the surrounding land is abandoned (rewilding). However, vegetation restoration by land separation, namely secondary succession following farmland abandonment and tree plantations, would provide these triple benefits only at the landscape or regional scales as this restoration type is at the expense of field-level agricultural production. At the landscape level, restoration of riparian vegetation is a priority whereas strategic revegation of road sides and roundabouts should be carefully planned to avoid risks for wildlife and drivers. Beyond scientific and technical research, an increase in such restoration projects is needed if we want to halt environmental degradation and biodiversity loss and meet the CBD and UE goals (see Chap. 11). We propose widespread expansion of highly specific actions to benefit wildlife and specific ecosystem services, particularly habitat provision and seed dispersion for triggering passive restoration after land abandonment leading to rewilding. Financial support, public awareness, education and training, particularly of farmers, are necessary to accomplish such objectives.

Acknowledgments Figures 7.1 and 7.2 were produced by Alejandra Toledo and by Luis Monje, respectively, following the authors' directions. Henrique Pereira and Laetitia Navarro provided useful comments on a previous version of this manuscript. Projects from the Spanish Ministry of Science and Education (CGL2010-18312), the Government of Madrid (S2009AMB-1783, REMEDINAL-2) and NERC (Wessex-BESS) are currently providing financial support for this body of research.

Open Access This chapter is distributed under the terms of the Creative Commons Attribution Noncommercial License, which permits any noncommercial use, distribution, and reproduction in any medium, provided the original author(s) and source are credited.

\section{References}

Barnes, G., \& Williamson, T. (2006). Hedgerow history: Ecology, history and landscape character. Macclesfield: Windgather Press.

Blanco, J. C., \& Cortés, Y. (2007). Dispersal patterns, social structure and mortality of wolves living in agricultural habitats in Spain. Journal of Zoology, 273, 114-124.

Bremer, L. L., \& Farley, K. A. (2010). Does plantation forestry restore biodiversity or create green deserts? A synthesis of the effects of land-use transitions on plant species richness. Biodiversity Conservation, 19, 3893-3915. 
Bullock, J. M., \& Moy, I. L. (2004). Plants as seed traps: Inter-specific interference with dispersal. Acta Oecologica, 25, 35-41.

Bullock, J. M., Aronson, J., Newton, A., C., Pywell, R. F., \& Rey-Benayas, J. M. (2011). Restoration of ecosystem services and biodiversity: Conflicts and opportunities. Trends in Ecology and Evolution, 26, 541-549.

Corbin, J. D., \& Holl, K. D. (2012). Applied nucleation as a forest restoration strategy. Forest Ecology and Management, 265, 37-46.

Cuesta, B., Villar-Salvador, P., Puértolas, J., Rey Benayas, J. M., \& Michalet, R. (2010). Facilitation of Quercus ilex in Mediterranean shrubland is explained by both direct and indirect interactions mediated by herbs. Journal of Ecology, 98, 687-696.

de Snoo, G. R., Herzon, I., Staats, H., Burton, R. J. F., Schindler, S., van Dijk, J., Lokhorst, A. M., Bullock, J. M., Lobley, M., Wrbka, T., Schwarz, G., \& Musters, C. J. M. (2013). Toward effective nature conservation on farmland: Making farmers matter. Conservation Letters, 6, 66-72.

Debain, S., Chadaeuf, J., Curt, T., Kunstler, G., \& Lepart, J. (2007). Comparing effective dispersal in expanding population of Pinus sylvestris and Pinus nigra in calcareous grassland. Canadian Journal of Forest Research, 37, 705-718.

DeMars, C. A., Rosenberg, D. K., \& Fontaine, J. B. (2010). Multi-scale factors affecting bird use of isolated remnant oak trees in agro-ecosystems. Biological Conservation, 143, 1485-1492.

Directorate-General for Agriculture and Rural Development. (2012). Rural development in the European Union. Statistical and Economic Information. Report 2012. Brussels.

Dovciak, M., Hrivnak, R., Ujhazy, K., \& Gomory, D. (2008). Seed rain and environmental controls on invasion of Picea abies into grassland. Plant Ecology, 194, 135-148.

Dwyer, J. M., Fensham, R. J., \& Buckley, Y. M. (2010). Agricultural legacy, climate, and soil influence the restoration and carbon potential of woody regrowth in Australia. Ecological Applications, 20, 1838-1850.

Ellis, E. C., \& Ramankutty, N. (2008). Putting people in the map: Anthropogenic biomes of the world. Frontiers in Ecology and the Environment, 6, 439-447.

European Bird Census Council. (2010). Pan-European common bird monitoring scheme (on line). http://www.ebcc.info/. Accessed 28 Feb 2012.

Fahrig, L., \& Rytwinski, T. (2009). Effects of roads on animal abundance: An empirical review and synthesis. Ecology and Society, 14(1), 21.

FAOSTAT. http://faostat3.fao.org/home/index.html\#DOWNLOAD. Accessed 9 April 2013.

Felton, A., Knight, E., Wood, J., Zammit, C., \& Lindenmayer, D. (2010). A meta-analysis of fauna and flora species richness and abundance in plantations and pasture lands. Biological Conservation, 143, 545-554.

Fischer, J., Brosi, B., Daily, G. C., Ehrlich, P. R., Goldman, R., Goldstein, J., Lindenmayer, D. B., Manning, A. D., Mooney, H. A., Pejchar, L., Ranganathan, J., \& Tallis, H. (2008). Should agricultural policies encourage land sparing or wildlife-friendly farming? Frontiers in Ecology and the Environment, 6, 382-387.

Fischer, J., Stott, J., \& Law, B. S. (2010). The disproportionate value of scattered trees. Biological Conservations, 143, 1564-1567.

Flynn, D. F. B., Gogol-Prokurat, M., Nogeire, T., Molinari, N., Richers, B. T., Lin, B. B., Simpson, N., Mayfield, M. M., \& DeClerck, F. (2009). Loss of functional diversity under land use intensification across multiple taxa. Ecology Letters, 12, 22-33.

Foley, J. A., DeFries, R., Asner, G. P., Barford, C., Bonan, G., Carpenter, S. R., Chapin, F. S., Coe, M. T., Daily, G. C., Gibbs, H. K., Helkowski, J. H., Holloway, T., Howard, E. A., Kucharik, C. J., Monfreda, C., Patz, J. A., Prentice, I. C., Ramankutty, N., \& Snyder, P. K. (2005). Global consequences of land use. Science, 309, 570-574.

Foley, J. A., Ramankutty, N., Brauman, K. A., Cassidy, E. S., Gerber, J. S., Johnston, M., Mueller, N. D., O'Connell, C., Ray, D. K., West, P. C., Balzer, C. B., Bennett, L. M., Carpenter, S. R., Hill, J., Monfreda, C., Polasky, S., Rockstrom, J., Sheehan, J., Siebert, S., Tilman, D., \& Zaks, D. P. M. (2011). Solutions for a cultivated planet. Nature, 478, 337-342.

Forget, G., Carreau, C., Le Coeur, D., \& Bernez, I. (2013). Ecological restoration of headwaters in a rural landscape (Normandy, France): A passive approach taking hedge networks into account for riparian tree recruitment. Restoration Ecology, 21, 96-104. 
García, D., Zamora, R., \& Amico, G. (2010). Birds as suppliers of seed dispersal in temperate ecosystems: Conservation guidelines from real-world landscapes. Conservation Biology, 24, 1070-1079.

Hodder, K. H., \& Bullock, J. M. (2010). Nature without nurture. In M. Hall (Ed.), Restoration and history: The search for a usable environmental Past (pp. 223-235). Abingdon: Routledge.

Hooftman, D. A. P., \& Bullock, J. M. (2012). Mapping to inform conservation: A case study of changes in semi-natural habitats and their connectivity over 70 years. Biological Conservation, $145,30-38$.

International Union for Conservation of Nature. (2012). IUCN Guidelines for reintroductions and other conservation translocations. http://www.issg.org/pdf/publications/Translocation-Guidelines-2012.pdf. Accessed 4 April 2013.

Jackson, L. E., Pascual, U., \& Hodgkin, T. (2007). Utilizing and conserving agrobiodiversity in agricultural landscapes. Agriculture, Ecosystems and the Environment, 121, 196-210.

Jensen, T. S., \& Nielsen, O. F. (1986). Rodents as seed dispersers in a heath oak wood succession. Oecologia, 70, 214-221.

Jordano, P., Garcia, C., Godoy, J. A., \& Garcia-Castano, J. L. (2007). Differential contribution of frugivores to complex seed dispersal patterns. Proceedings of the National Academy of Sciences, 104, 3278-3282.

Kleijn, D., Baquero, R. A., Clough, Y., Díaz, M., Esteban, J., Fernández, F., Gabriel, D., Herzog, F., Holzschuh, A., Jöhl, R., Knop, E., Kruess, A., Marshall, E. J., Steffan-Dewenter, I., Tscharntke, T., Verhulst, J., West, T. M., \& Yela, J. L. (2006). Mixed biodiversity benefits of agro-environment schemes in five European countries. Ecology Letters, 9, 243-254.

Kohler, F., Vandenberghe, C., Imstepf, R., \& Gillet, F. (2008). Restoration of threatened arable weed communities in abandoned mountainous crop fields. Restoration Ecology, 19, 62-69.

Kollmann, J., \& Schill, H. P. (1996). Spatial patterns of dispersal, seed predation and germination during colonization of abandoned grassland by Quercus petraea and Corylus avellana. Vegetatio, 125, 193-205.

Kunstler, G., Thuiller, W., Curt, T., Bouchaud, M., Jouvie, R., Deruette, F., \& Lepart, J. (2007). Fagus sylvatica L. recruitment across a fragmented Mediterranean Landscape, importance of long distance effective dispersal, abiotic conditions and biotic interactions. Diversity and Distributions, 13, 799-807.

Laborde, J., \& Thompson, K. (2009). Post-dispersal fate of hazel (Corylus avellana) nuts and consequences for the management and conservation of scrub-grassland mosaics. Biological Conservation, 142, 974-981.

Noordijk, J., Musters, C. J. M., van Dijk, J., \& de Snoo GR. (2010). Invertebrates in field margins: taxonomic group diversity and functional group abundance in relation to age. Biodiversity Conservation, 19, 3255-3268.

Oliver, T., Roy, D. B., Hill, J. K., Brereton, T., \& Thomas, C. D. (2010). Heterogeneous landscapes promote population stability. Ecology Letters, 13, 473-484.

Ozinga, W. A., Romermann, C., Bekker, R. M., Prinzing, A., Tamis, W. L. M., Schaminee, J. H. J., Hennekens, S. M., Thompson, K., Poschlod, P., Kleyer, M., Bakker, J. P., \& van Groenendael, J. M. (2009). Dispersal failure contributes to plant losses in NW Europe. Ecology Letters, 12, $66-74$.

Pereira, M., \& Rodríguez, A. (2010). Conservation value of linear woody remnants for two forest carnivores in a Mediterranean agricultural landscape. Journal of Applied Ecology, 47, 611-620.

Phalan, B., Onial, M., Balmford, A., \& Green, R. E. (2011). Reconciling food production and biodiversity conservation: Land sharing and land sparing compared. Science, 333, 1289-1291.

Pilgrim, E. S., Macleod, C. J. A., Blackwell, M. S. A., Bol, R., Hogan, D. V., Chadwick, D. R., Cardenas, L., Misselbrook, T. H., Haygarth, P. M., Brazier, R. E., Hobbs, P., Hodgson, C., Jarvis, S., Dungait, J., Murray, P. J., Firbank, L. G., \& Donald, L. S. (2010). Interactions among agricultural production and other ecosystem services delivered from European temperate grassland systems. Advances in Agronomy, 109, 117-154. 
Poggio, S. L., Chaneton, E. J., \& Ghersa, C. M. (2010). Landscape complexity differentially affects alpha, beta, and gamma diversity of plants occurring in fencerows and crop fields. Biological Conservation, 143, 2477-2486.

Pons, J., \& Pausas, J. G. (2007). Acorn dispersal estimated by radio-tracking. Oecologia, 153, 903-911.

Reino, L., Porto, M., Morgado, R., Carvalho, F., Mira, A., \& Beja, P. (2010). Does afforestation increase bird nest predation risk in surrounding farmland? Forest Ecology and Management, 260, 1359-1366.

Rey Benayas, J. M. (2012). Restauración de campos agrícolas sin competir por el uso de la tierra para aumentar su biodiversidad y servicios ecosistémicos. Investigación Ambiental. Ciencia y Política Pública, 4, 101-110.

Rey Benayas, J. M., \& Bullock, J. M. (2012). Restoration of biodiversity and ecosystem services on agricultural land. Ecosystems, 15, 883-889.

Rey Benayas, J. M., Martins, A., Nicolau, J. M., \& Schulz, J. (2007). Abandonment of agricultural land: an overview of drivrs and consequences. Perspectives in Agriculture, Veterinary Sciences, Nutrition and Natural Resources, 2(057), 1-14.

Rey Benayas, J. M., Bullock, J. M., \& Newton, A. C. (2008). Creating woodland islets to reconcile ecological restoration, conservation, and agricultural land use. Frontiers in Ecology and the Environment, 6, 329-336.

Rey Benayas, J. M., Galván, I., \& Carrascal, L. M. (2010). Differential effects of vegetation restoration in Mediterranean abandoned cropland by secondary succession and pine plantations on bird assemblages. Forest Ecology and Management, 260, 87-95.

Romero-Calcerrada, R., \& Perry, G. L. W. (2004). The role of land abandonment in landscape dynamics in the SPA 'Encinares del rio Alberche y Cofio, Central Spain, 1984-1999. Landscape and Urban Planning, 66, 217-232.

Rounsevell, M. D. A., Ewert, F., Reginster, I., Leemans, R., \& Carter, T. R. (2005). Future scenarios of European agricultural land use II. Projecting changes in cropland and grassland. Agriculture, Ecosystems \& Environment, 107, 117-135.

Sánchez-Oliver, J., Rey Benayas, J. M., \& Carrascal, L. M. (2014). Differential effects of local habitat and landscape characteristics on bird communities in Mediterranean afforestations motivated by the EU Common Agrarian Policy. European Journal of Wildlife Research, 60, $135-143$.

Stanturf, J. A., Palik, B. J., \& Dumroese, R. K. (2014). Contemporary forest restoration: A review emphasizing function. Forest Ecology and Management, 331, 292-323.

Stoyan, D., \& Wagner, S. (2001). Estimating the fruit dispersion of anemochorous forest trees. Ecological Modeling, 45, 35-47.

TEEB. (2010). The economics of ecosystems and biodiversity: Mainstreaming the economics of nature: A synthesis of the approach, conclusions and recommendations of TEEB. http://www. teebweb.org/. Accessed 10 Sep 2013.

Thompson, J. R., Moilanen, A., Vesk, P. A., Bennett, A. F., \& Mac Nally, R. (2009). Where and when to revegetate?: A quantitative method for scheduling landscape reconstruction. Ecological Applications, 19, 817-827.

Tscharntke, T., Klein, A. M., Kruess, A., Steffan-Dewenter, I., \& Thies, C. (2005). Landscape perspectives on agricultural intensification and biodiversity-ecosystem service management. Ecology Letters, 8, 857-874. 